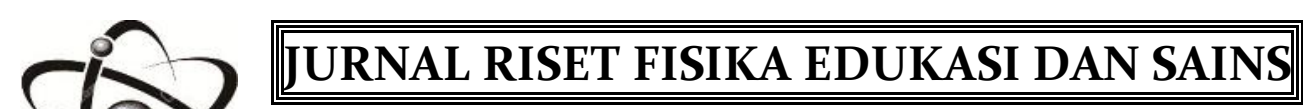

Education and Science Physics Journal

E- ISSN : 2503-3425

P- ISSN : 2407-3563

JRFES Vol 1, No 2 (2015) 99-106

http://ejournal.stkip-pgri-sumbar.ac.id/index.php/JRFES

\title{
PRAKTIKALITAS HANDOUT FISIKA SMA BERBASIS PENDEKATAN SCIENCE ENVIRONMENT TECHNOLOGY AND SOCIAL PADA MATERI LISTRIK DINAMIS
}

\author{
Megasyani Anaperta \\ Staf Pengajar Prodi Pendidikan Fisika STKIP PGRI Sumatera Barat; \\ Email: mega.syani@yahoo.com \\ http://dx.doi.org/10.22202/jrfes.2015.v1i2.1405
}

\section{Abstract}

The purpose of physics in high school according to the National Standards Indonesia is not yet achieved is the goal on two points, namely, developing an understanding of a wide variety of natural phenomena, concepts and principles of science that are useful and can be applied in everyday life. One medium used is a handout with the chosen approach is the approach the goal line with the demands of the curriculum, 2013. That approach is Science Environment Technology Society (SETS) in Dynamic Electrical material. This type of research is the development of research (research and development) using the model proposed by Plomp (2010) which consists of the initial investigation phase (preliminary research), phases of design, realization (prototyping phase) and phase assessment (assessment phase). The research results are to be obtained that the handout material electricity Dynamic approach Science Environment Technology Society (SETS) Value practicality based on the observation sheets and questionnaires practicality of the draft by the teacher in high school Adabiah 2 Padang categorized practically can be seen from the test results practicalities obtained average percentage keterlaksanaan RPP is $92 \%$, the average teacher questionnaire responses $94 \%$, and the average student questionnaire responses $92 \%$. Research shows that using a handout High School Physics Science Environment Technology Society (SETS) are in the category of very valid and very practical so worth applied to the learning process.

Keywords: Dynamic Electricity, Environment Science Technology Society (SETS), the practicalities

\begin{abstract}
ABSTRAK
Tujuan pelajaran Fisika di SMA menurut Standar Nasional Pendidikan Indonesia yang belum tercapai adalah tujuan pada poin 2 yaitu, mengembangkan pemahaman tentang berbagai macam gejala alam, konsep dan prinsip IPA yang bermanfaat dan dapat diterapkan dalam kehidupan sehari-hari. Salah satu media yang digunakan adalah handout dengan pendekatan yang dipilih ini adalah pendekatan yang tujuannya sejalan dengan tuntutan kurikulum 2013. Pendekatan itu adalah Science Environment Technology Society (SETS) dalam materi Listrik Dinamis Jenis penelitian yang digunakan adalah penelitian pengembangan (research and development) menggunakan model yang dikemukakan oleh Plomp (2010) yang terdiri atas fase investigasi awal (preliminary research), fase perancangan, realisasi (prototyping phase) dan fase penilaian (assessment phase). Dari hasil penelitian yang dilakukan diperoleh bahwa handout materi listrik Dinamis menggunakan pendekatan Science Environment Technology Society (SETS) Nilai kepraktisan berdasarkan lembar observasi dan angket kepraktisan rancangan oleh guru di SMA Adabiah 2 Padang dikategori praktis dapat dilihat dari hasil uji praktikalitas diperoleh persentase rata-rata keterlaksanaan RPP adalah 92\%, rata-rata angket respon guru 94\%, dan rata-rata angket respon siswa 92\%. Penelitian menunjukkan bahwa handout Fisika SMA menggunakan Science Environment Technology Society (SETS) berada dalam kategori sangat valid dan sangat praktis sehingga layak diterapkan pada proses pembelajaran.
\end{abstract}

Kata kunci : Listrik Dinamis, Science Environment Technology Society (SETS), Praktikalitas 


\section{PENDAHULUAN}

Fisika merupakan ilmu yang mempelajari jawaban atas pertanyaan kenapa, mengapa, dan bagaimana gejalagejala alam dapat terjadi. Disamping itu fisika juga merupakan bidang ilmu yang memegang peranan penting dalam perkembangan ilmu pengetahuan dan teknologi.

Pembelajaran yang menantang akan memacu kreativitas siswa. Ini penting untuk menyiapkan sumber daya manusia Indonesia yang bermutu dan siap bersaing di dunia global.

usaha telah dilakukan oleh pemerintah dalam upaya meningkatkan mutu pendidikan seperti melalui penyempurnaan kurikulum, pengadaan buku ajar, peningkatan mutu guru, sertifikasi guru, peningkatan manajemen pendidikan dan peningkatan kesejahteraan guru. Namun demikian berbagai indikator menunjukkan bahwa mutu pendidikan belum meningkat secara signifikan.

Berdasarkan pengamatan di lapangan, pelaksanaan pembelajaran fisika di SMA Adabiah 2 Padang kelas X juga menunjukkan belum sesuai dengan tujuan pembelajaran yang diharapkan, peneliti memperoleh fakta bahwa pemahaman peserta didik terhadap berbagai gejala alam belum begitu berkembang, rasa ingin tahu peserta didik terhadap fisika dan hubungannya dengan lingkungan dan teknologi masih sulit dimunculkan. Peserta didik kesulitan dalam mengintegrasikan kemampuan yang sudah dimiliki dengan kemampuan baru yang akan diterima. Peserta didik belum mampu mengaplikasikan prinsip Fisika yang sudah dipelajari terhadap fenomena alam dan teknologi yang tengah berkembang di masyarakat. Permasalahan-permasalahan tersebut pada intinya dikarenakan dasar-dasar pemahaman fisika peserta didik yang belum mantap, peserta didik hanya memahami materi sebatas penyelesaian hitungan matematis, rumus-rumus yang harus dihapalkan, sementara itu aplikasi materi pelajaran ke dalam kehidupan sehari-hari masih sangat kurang. Jadi tujuan pembelajaran fisika di kelas $\mathrm{X}$ SMA Adabiah 2 Padang belum tercapai dengan baik, hal ini di tunjukkan dengan belum tercapainya KKM yang ditetapkan oleh sekolah untuk mata pelajaran fisika yaitu 75 .

Menurut guru yang mengajar di SMA Adabiah 2 Padang, hasil belajar juga dipengaruhi Dampak dari pengembangan pembelajaran yang hanya menitikberatkan pada konsep-konsep yang terdapat dalam buku, tidak mengkondisikan siswa untuk mengkonstruksi konsep sendiri sehingga siswa tidak terlibat dalam penemuan informasi.

Ketersediaan perangkat pembelajaran di sekolah adalah salah satu faktor yang sangat mempengaruhi kualitas pembelajaran. Cara guru mengajar berkaitan erat dengan perangkat yang digunakan, perangkat pembelajaran yang baik seharusnya memfasilitasi peserta didik untuk mengkonstruksikan pengetahuannya dan menemukan sendiri konsep melalui masalah-masalah yang dihadapi dalam kehidupan sehari-hari sehingga mengembangkan pola pikir peserta didik.

Guru di SMA Adabiah Padang belum menggunakan perangkat pembelajaran yang mampu membuat peserta didik dapat menerapkan ilmu Fisika terhadap lingkungan, teknologi dan masyarakat. Hal ini dapat dilihat dari RPP yang digunakan oleh guru. Pada RPP yang digunakan oleh guru belum tergambar kegiatan yang dapat mengaktifkan peserta didik dalam proses pembelajaran. Langkah-langkah dalam kegiatan pembelajaran merupakan langkah-langkah kegiatan pembelajaran konvensional, yaitu peserta didik diberikan konsep, rumus dan contoh soal, 
kemudian di akhir pembelajaran peserta didik diberikan latihan..

Upaya yang dapat dilakukan guru untuk mengatasi masalah ini di antaranya adalah memilih dan menggunakan pendekatan pembelajaran yang relevan. Sejumlah peneliti juga telah melakukan penelitian untuk menemukan pendekatan pembelajaran yang cocok dalam mengatasi permasalahan yang berhubungan dengan aplikasi fisika. Pendekatan yang dipilih ini adalah pendekatan yang tujuannya sejalan dengan tuntutan kurikulum 2013. Pendekatan yang dipilih ini adalah pendekatan yang tujuannya sejalan dengan tuntutan kurikulum 2013. Pendekatan pembelajaran yang dimaksud adalah pendekatan pembelajaran Science Environment Technology Society (SETS).

Menurut Widyatiningtyas (2009), pendekatan SETS dapat menghubungkan kehidupan dunia nyata anak sebagai anggota masyarakat dengan kelas sebagai ruang belajar sains. Proses pendekatan ini dapat memberikan pengalaman belajar bagi anak dalam mengidentifikasi potensi masalah, mengumpulkan data yang berkaitan dengan masalah, mempertimbangkan solusi alternatif, dan mempertimbangkan konsekuensi berdasarkan keputusan tertentu.

\section{METODE PENELITIAN}

Jenis penelitian adalah penelitian pengembangan (Research and development) untuk membuat suatu produk yaitu perangkat pembelajaran berorientasi Pendekatan SETS. Penelitian diawali dengan perencanaan perangkat yang akan dibuat pada pembelajaran Fisika SMA materi Listrik Dinamisberbasis Pendekatan SETS ,dikembangkan dengan model McKenny.

Proses pengembangan perangkat dengan model McKenny terdiri dari tiga tahap yaitu, preliminary, prototyping stage, dan assesment stage. tahappreliminarylebih menekankan relevansi dan konsistensi perangkat pembelajaran terutama pada validitas dan sebagian kecil praktikalitasnya. Pada tahapprototyping stagedilakukan perancangan prototype terhadap perangkat pembelajaran tahap pengembangan dimulai dengan konsistensi dan praktikalitas, sedangkan tahap assesment stage mencakup praktikalitas

Sebagai awal dari pengembangan dilakukanlah tahap preliminary, dengan menganalisis struktur isi, konsep dan peserta didik. Tahap prototyping stagesalah satunya dengan menguji validitas produk. Validitas perangkat yang diuji adalah validitas isi (content validity) dan validitas konstruk (construct validity). Validitas isi mengandung arti bahwa isi dari perangkat pembelajaran yang dikembangkan sesuai dengan isi kurikulum yang berlaku. Dikatakan baik, jika isinya dapat mengukur dan mencakup semua domain dan tujuan khusus yang ingin dicapai dalam kurikulum. Sementara itu, validitas konstruk berarti perangkat pembelajaran yang telah dikembangkan sesuai dengan konstruksi teori-teori yang mendukung pembelajaran.

\section{HASIL DAN PEMBAHASAN}

Hasil analisis pada tahap Preliminary dapat diuraikan sebagai berikut:

1. Analisis Strutur isi (kurikulum) Muatan kurikulum 2013 kelas X SMA Adabiah 2 Padang kelompok peminatan matematika dan ilmu-ilmu alam materi Listrik Dinamis dan penerapannya dengan kompetensi inti (KI):

KI Menghayati dan

1: mengamalkan ajaran agama yang dianutnya.

KI Menghayati dan

2: mengamalkan perilaku jujur, disiplin, tanggung jawab, peduli (gotong royong, kerjasama, toleran, damai), 
santun, responsif dan proaktif dan menunjukkan sikap sebagai bagian dari solusi atas berbagai permasalahan dalam berinteraksi secara efektif dengan lingkungan sosial dan alam serta dalam menempatkan diri sebagai cerminan bangsa dalam pergaulan dunia.

KI Memahami, menerapkan, 3: menganalisis pengetahuan faktual, konseptual, prosedural berdasarkan rasa ingintahunya tentang ilmu pengetahuan, teknologi, seni, budaya, dan humaniora dengan wawasan kemanusiaan, kebangsaan, kenegaraan, dan peradaban terkait penyebab fenomena dan kejadian, serta menerapkan pengetahuan prosedural pada bidang kajian yang spesifik sesuai dengan bakat dan minatnya untuk memecahkan masalah.

KI Mengolah, menalar, dan 4: menyaji dalam ranah konkret dan ranah abstrak terkait dengan pengembangan dari yang dipelajarinya di sekolah secara mandiri, dan mampu menggunakan metoda sesuai kaidah keilmuan.

Adapun Kompetensi Dasar (KD) materi hukum Newton dan penerapannya adalah:

KD Menyadari kebesaran Tuhan 1.1: yang menciptakan dan mengatur alam jagad raya melalui pengamatan fenomena alam fisis dan pengukurannya.

KD Menunjukkan perilaku

2.1: ilmiah (memiliki rasa ingin tahu; objektif; jujur; teliti; cermat; tekun; hati-hati; bertanggung jawab; terbuka; kritis; kreatif; inovatif dan peduli lingkungan) dalam aktivitas sehari-hari sebagai wujud implementasi sikap dalam melakukan percobaan, melaporkan, dan berdiskusi.

KD Menghargai kerja individu

2.2: dan kelompok dalam aktivitas sehari-hari sebagai wujud implementasi melaksanakan percobaan dan melaporkan hasil percobaan.

KD Mengevaluasi prinsip kerja

3.2: peralatan listrik searah (DC) dalam kehidupan sehari-hari

KD Menganalisis rangkaian arus

3.8: bolak-balik (AC) serta penerapannya

KD Melakukan percobaan untuk 4.2: menyelidiki rangkaian listrik

KD Memecahkan masalah

4.8: terkait rangkaian arus bolak-balik (AC) dalam kehidupan sehari-hari.

Pelaksanaan KI dan KD tersebut dialokasikan sebanyak 4 x 2 JP ( 8 x 45 menit)

2. Analisis Konsep

Hasil analisis materi merupakan dasar untuk menentukan konsep utama pada materi listrik dinamis. Konsep utama dari materi listrik dinamis dikorelasikan dengan langkah-langkah pendekatan SETS dimana pendekatan ini dapat digunakan untuk membantu keterlaksanaan proses pembelajaran secara optimal dengan tujuan akhir meningkatnya hasil belajar peserta didik pada kompetensi sikap, pengetahuan, dan keterampilan peserta didik.

Materi pembelajaran diidentifikasi dengan mengajukan pertanyaan tentang kompetensi dasar yang harus dikuasai peserta didik. Dengan mengacu pada kompetensi dasar, dapat diperoleh apakah 
materi berupa fakta, konsep, prinsip, atau prosedur. Misalnya pada KD 3.8 Fisika kelas $\mathrm{X}$ kata kerja operasional yang digunakan adalah Menganalisis. Menurut KBBI, kata "menganalisis" mengandung makna penguraian suatu pokok atas berbagai bagiannya dan penelaahan bagian itu sendiri serta hubungan antar bagian untuk memperoleh pengertian yang tepat dan pemahaman arti keseluruhan.

\section{Analisis Peserta Didik}

Uji coba perangkat pembelajaran dilakukan pada siswa kelas $\mathrm{X}_{1}$ di SMA Adabiah 2 Padang dimana peserta didik berada pada tahap operasional formal. Menurut Sanjaya (2006:43), pada tahap formal peserta didik sudah sistematik dan meliputi proses-proses yang komplek. Operasionalnya tidak saja terbatas pada hal konkret, akan tetapi pada operasional lainnya. Siswa sudah mulai mampu memecahkan berbagai masalah yang dihadapkan. Diharapkan peserta didik sudah mempunyai pengetahuan prosedural dan metakognitif dalam ilmu pengetahuan, teknologi, seni, dan budaya dengan wawasan kemanusiaan, kebangsaan, kenegaraan, dan peradaban terkait penyebab fenomena dan kejadian.

Silabus yang dikembangkan berbasis pendekatan SETS. Pengembangan silabus sebagai acuan pengembangan RPP memuat identitas mata pelajaran, KI, KD, materi pembelajaran, kegiatan pembelajaran, penilaian, alokasi waktu, dan sumber belajar yang mengacu pada pencapaian kompetensi dasar sesuai dengan karakteristik mata pelajaran. Silabus ini dikembangkan dengan menggunakan Microsoft Word 2007 dengan jenis font Cambria ukuran 12 spasi 1,15 .

2. Rencana Perangkat Pembelajaran (RPP) yang dikembangkan sesuai dengan pembelajaran yang tertera pada silabus, berbasis pendekatan SETS. RPP ini akan dikembangkan menggunakan
Microsoft Word 2007 dengan jenis font Californian FB ukuran 12 spasi 1,5.

3. Handout disesuaikan dengan KI dan $\mathrm{KD}$ yang telah ditentukan dalam kurikulum. Uraian materi dibuat mengikuti tahap-tahap pada pendekatan SETS yang meliputi tahap 1 pendahuluan (invitasi, apersepsi, ekplorasi), tahap 2 (pembentukan prinsip), tahap 3 (aplikasi prinsip), tahap 4 (pemantapan prinsip) dan tahap 5 (penilaian). Handout dikembangkan menggunakan program Microsoft Word 2007 dengan jenis font Century Schoolbook ukuran antara 10 - 12 dan spasi antara $1-1,5$.

5. Penilaian dikembangkan dengan berpedoman Permendikbud No. 66 Tahun 2013 tentang Standar Penilaian Pendidikan. Penilaian dikembangkan untuk mengukur kompetensi sikap, pengetahuan, dan keterampilan. Kompetensi sikap dinilai dalam bentuk skala penilaian yang terdiri dari skala penilaian sikap spiritual dan sosial. Penilaian pengetahuan dikembangkan dalam bentuk soal-soal tes. Penilaian kompetensi keterampilan dikembangkan dalam bentuk skala penilaian (rating scale) yang dilengkapi rubrik. Pembuatan lembar penilaian menggunakan Microsoft Word 2007 dengan menggunakan jenis tulisan Times New Roman ukuran 10 spasi 1,15 .

\section{KESIMPULAN}

Berdasarkan pengembangan dan uji coba yang telah dilakukan terhadap perangkat pembelajaran berbasis pendekatan SETS pada materi listrik dinamis, didapat kesimpulan sebagai berikut.

1. Validitas perangkat pembelajaran materi listrik dinamis berbasis pendekatan SETS yang dinilai oleh 5 orang validator menunjukkan bahwa perangkat pembelajaran berbasis pendekatan SETS pada materi listrik dinamis sangat valid. 
2. Praktikalitas yang dinilai dari pengamatan terhadap keterlaksanaan RPP oleh observer dan hasil analisis angket respon guru serta angket respon siswa menunjukkan perangkat pembelajaran berbasis pendekatan SETS pada materi listrik dinamis sangat praktis di dalam penggunaannya.

\section{DAFTAR KEPUSTAKAAN}

Akker, McKenny. 2006. Educational Design Research. New York: Routleddge

Binadja, Achmad. 1999a. Hakekat dan Tujuan Pendidikan SETS (Science, Environment, Technology, and Society) dalam Konteks Kehidupan dan Pendidikan yang Ada. Makalah ini disajikan dalam Seminar Lokakarya pendidikan SETS, kerjasama antara SEAMEO RECSAM dan Unnes, Semarang, 14-15 Desember 1999.

Binadja, Achmad. 1999b. Pendidikan SETS (Science, Environment, Technology,

and Society) Penerapannya pada Pengajaran. Makalah ini disajikan dalam Seminar Lokakarya pendidikan SETS, kerjasama antara SEAMEO RECSAM dan Unnes, Semarang, 14-15 Desember 1999. Binadja, Achmad. 2002. Program Studi

Pendidikan IPA (bervisi SETS)

Pemikiran dalam SETS (Sains

Environment Technology Society).

Semarang: PPS Unnes Press.

Daryanto. 2010. Belajar Mengajar. Bandung: Yrama Widya.

Del Rosario, Bernadete. 2009. Science, Technology, Society and Environment (STSE) Approach in Environmental Science for Nonscience Student in a Local Culture. Liceo Journal of Higher Education Research Science and Technology Section vol.6, No 1, December 2009 ISSN: 2094-1064
Depdiknas. 2005. Materi Pelatihan Terintegrasi Ilmu Pengetahuan Alam. Jakarta: Dikdasmen

Hindarto, N. 2010. Pendidikan Karakter Dalam Pembelajaran Fisika Modern. Semarang. Unnes

Fauzan, Ahmad. 2002. Laporan Penelitian Hibah Bersaing XII/I Perguruan Tinggi. Padang: UNP

Jeremy N. Bailenson and Nick Yee.dkk. 2008. The Use Of Immersive Virtual Reality In The Learning Sciences: Digital Transformations Of Teachers, Students, And Social Context. The Journal of The Learning Sciences, 17: 102-141, 2008 Copyright (C) Taylor \& Francis Group, LLC ISSN: 10508406 print / 1532-7809 online DOI:

10.1080/10508400701793141

Juniati. 2009. Peningkatan Aktivitas, Motivasi Dan Hasil Belajar Peserta Didik Dengan Metode SETS Di Kelas IXe Smp Negeri 3 Purworejo, Jawa Tengah Pada Konsep Energi Dan Daya Listrik. Jawa Tengah. Jurnal Berkala Fisika Indonesia Volume 2 Nomor 1 Juli 2009

Kaifa Slameto. 1995. Belajar dan Faktorfaktor yang Mempengaruhinya. Jakarta : PT. Rineka Cipta

Kamus Bahasa Indonesia. Jakarta: Pusat Bahasa. Cet. I.

Kemdiknas. 2010. Desain Induk Pendidikan Karakter. Jakarta: Kementerian Pendidikan Nasional.

Koes, H. 2003. Strategi Pembelajaran Fisika. Bandung : JICA.

Lickona, Thomas. 1991. Educating for Character: How Our School Can Teach Respect and Responsibility. New York, Toronto, London, Sydney, Aucland: Bantam books.

Nurwahyunani, Atip. 2011. Penerapan Pendekatan SETS (Science, 
Environment, Technology, Society) Untuk Meningkatkan Hasil Belajar Dan Keterampilan Mengelola Lingkungan. IKIP PGRI Semarang

Nurmasyiah. 2008. Peningkatan Aktivitas dan Hasil Belajar Kimia Siswa Kelas X SMA N Plus Prov. Riau melalui Penerapan Model STM. UNP

Pedretti, Erminia G. Dkk. 2006. Promoting Issues-based STSE Perspectives in Science Teacher Education: Problems of Identity and Ideology. University of Toronto. Journal of Science \& Education (2006) _ Springer 2006 DOI 10.1007/s11191-006-9060-8

Peraturan Menteri Pendidikan Dan Kebudayaan Republik Indonesia Nomor 65 Tahun 2013 Tentang Standar Proses Pendidikan Dasar Dan Menengah

Peraturan Menteri Pendidikan Dan Kebudayaan Nomor 69 Tahun 2013 Tentang Kerangka Dasar Dan Struktur Kurikulum Sekolah Menengah Atas/Madrasah Aliyah

Pemerintah Republik Indonesia. 2010. Kebijakan Nasional Pembangunan Karakter Bangsa Tahun 2010-2025. Jakarta: Pusat Kurikulum Balitbang Kemdiknas.

Peraturan Menteri Pendidikan Nasional Republik Indonesia Nomor 23 Tahun 2006 tentang Standar Kompetensi Lulusan untuk Satuan Pendidikan Dasar dan Menengah.

Peraturan Menteri Pendidikan Nasional Republik Indonesia Nomor 20 Tahun 2007 tentang Standar Penilaian Pendidikan.

Peraturan Menteri Pendidikan Nasional Republik Indonesia Nomor 41 Tahun 2006 tentang Standar Proses untuk Satuan Pendidikan Dasar dan Menengah.
Poedjiadi, A. 2005. Sains Teknologi Masyarakat Model Pembelajaran Kontekstual Bermuatan Nilai. Bandung: Remaja rosdakarya.

Pusat Bahasa Departemen Pendidikan Nasional. 2008.

Pusat Kurikulum Kemdiknas. 2009. Pengembangan dan Pendidikan Budaya dan Karakter Bangsa: Pedoman Sekolah. Jakarta: Pusat Kurikulum Balitbang Kemdiknas.

Raja, Kenneth P. 2009. Examintion of the science-technology-society with CurriculumApproach.http://www. cedu.niu.edu/scied/courses/ciee34 4/coursefiles_king/sts_reading.ht $\mathrm{m}$. Diakses tanggal 6 Januari 2014.

Purwiro Harjati Panduan.Matakuliah Micro Teaching

Ryan, Kevin \& Bohlin, K. E. 1999. Building Character in Schools: Practical Ways to Bring Moral Instruction to Life. San Francisco: Jossey Bass.

Slameto (2010). Belajar dan FaktorFaktor yang Mempengaruhinya. Jakarta : PT. Rineke Cipta.

Sudjana, Nana. 2010. Penilaian Hasil Proses Belajar Mengajar.

Bandung : Remaja Rosdakarya

Sugiyono.2009. Metode Penelitian Kuantitatif dan $R \& D$. Bandung : Alfabet

UU No. 14 Tahun 2005 tentang Guru danDosen

Undang-undang Republik Indonesia Nomor 20 Tahun 2003 tentang Sistem Pendidikan Nasional.

Yager, Robert E. 1994. Assessment Result with the Science/Technology/Society Approach. Science and Children (Journal). Pdf. File.

Yeung Chung Lee. 2006.Kidney failure and dialysis:a problem-solving approach in teaching Science,Technology and Society. Hong Kong : Institute of 
Education, Hong Kong SAR, China.

Wenda.K.bauchspiec,dkk. 2006. Science,

Technology, and Social a Socialogical Approach. UK : Blackwell Publishing Ltd

Widyatiningtyas, Reviandari. 2009.

Pembentukan Pengetahuan Sains,

Teknologi dan

Masyarakat dalam Pandangan

Pendidikan IPA. EDUCARE:

JurnalPendidikan dan Budaya.

http://educare.e-fkipunla.net.

Diakses 25 Januari 2014. 